\title{
Conceptual Urban Renewal Outlines Against Proposed Mediaspree Project at Holzmarkt Area in Berlin: A Proposal to Remodel Vibrant Urban Space
}

\author{
Sayed Ahmed a,* \\ a Department of Architecture, Leading University, Sylhet 3100, Bangladesh. \\ *Corresponding author Ph. No : 01707219556; Email: ar.sayedahmed@gmail.com \\ DOI: https://doi.org/10.54392/ajir2143 \\ Received: 26-08-2021; Revised: 13-10-2021; Accepted: 14-10-2021 Published: 16-10-2021
}

\begin{abstract}
The German capital city of Berlin, amongst all European cities, is well known as one of the most freethinking center but yet historical. Its industrial historic structures and heritage elements over the spree river shore are reanalyzed and reexamined in this case study with emphasis on club culture and social recreation. The important issue is that, the structures and architectural style of these few surviving buildings have the common features and also diversities which were never brought under light and even ignored to let them became hub for unsocial activities like drug dealing and unhygienic adobes for homeless peoples. To discover and recognize their current contribution and possible social attribute over the whole city fabric, the main construct of this paper is to rethink Berlin's so called public cohesion on the basis of recreational character and its associated urban order. The research question is: "What is the topmost role played by such built elements for formation of a distinct civic culture and keep Berlin alive?" To reveal the conceivable theoretical framework of this study will try to accentuate same facts and aspects followed by descriptive-analytical method and suggest independent and dependent variables, possible cooperative urban inventions based on the inhabitants' interest, protest and demands against privatization of Media Spree. Documentation, field survey, associated drawings, related photographs from different time intervals and model studying was helpful for analyzing the urban morphology. The proposed design will try to indicate that the historic industrial buildings, pubs and markets, art practice and the overall landscape has tremendous bilateral relations for the wellbeing of city dwellers; which could be shaped well into a main 'Axis' of cultural activities, which Berlin is not posed with currently.
\end{abstract}

Keywords: Collective Memory, Adaptive Reuse, Cultural hub, Urban renewal, Multidisciplinary Strategy.

\section{Introduction}

This area is under a threat from futuristic master plan of Media Spree proposed by Berlin Senate during the 1990 's. The plan aims to relocate Broadcaster companies on a 440 acre of land across the shores of the Spree River. (Figure 1) This ignited protest against privatization with public funds of such public places. If accomplished, this project will also raise the tenant rents; create adverse impact over their livelihoods and limit their earnings. A serious political concern is also involved, as leftist SPD and environmentalist Green Party jointly leading such upfront since 2008, they believe it's a 'project of valorization'. Internationally, such event exploded debates among the concerned experts of urban heritage conservation against such evil root. Many historic buildings and public places are being destroyed to make the way for contemporary lifestyle and its mad rush. Besides, for industrial monuments, things are more difficult as their decayed physical structures, out worn industrial tools and structural details are not given proper heed for preservation, for just being unaesthetic (Figure 2a, 2b).

\section{Location}

The given site was located in the eastern side of Berlin on the banks of river Spree. It stretches between Holzmarktstraße (north) to Köpenickertstraße (south) and Michaelkirchstraße (west) to Der Schillingbrücke (east). 
The site is surrounded by landmarks like controversially reconstructed Ostbahnhof rail station and Berlin TV tower of Alexanderplatz. It is accessible by U+S Bahn service, most effective combination of Metro line service in Europe (Figure 3, 4).

\section{Authenticity and Integrity}

The site included two historic buildings: an ice factory (Eisfabric) of $19^{\text {th }}$ century called; just at the middle and an egg cooling station (Eirkuhler), these are only of their kind that still surviving today, in Berlin and enlisted as protected historical buildings by Archaeology Department (Denkmalschutz). (Figure $5 a, 5 b$ ) The river bears the legacy of trade port where 150 foreign prisoners died in Nazi Regime. During the cold war era, it was an important industrial hold worked as East Germany's socialist 'Tissue.'

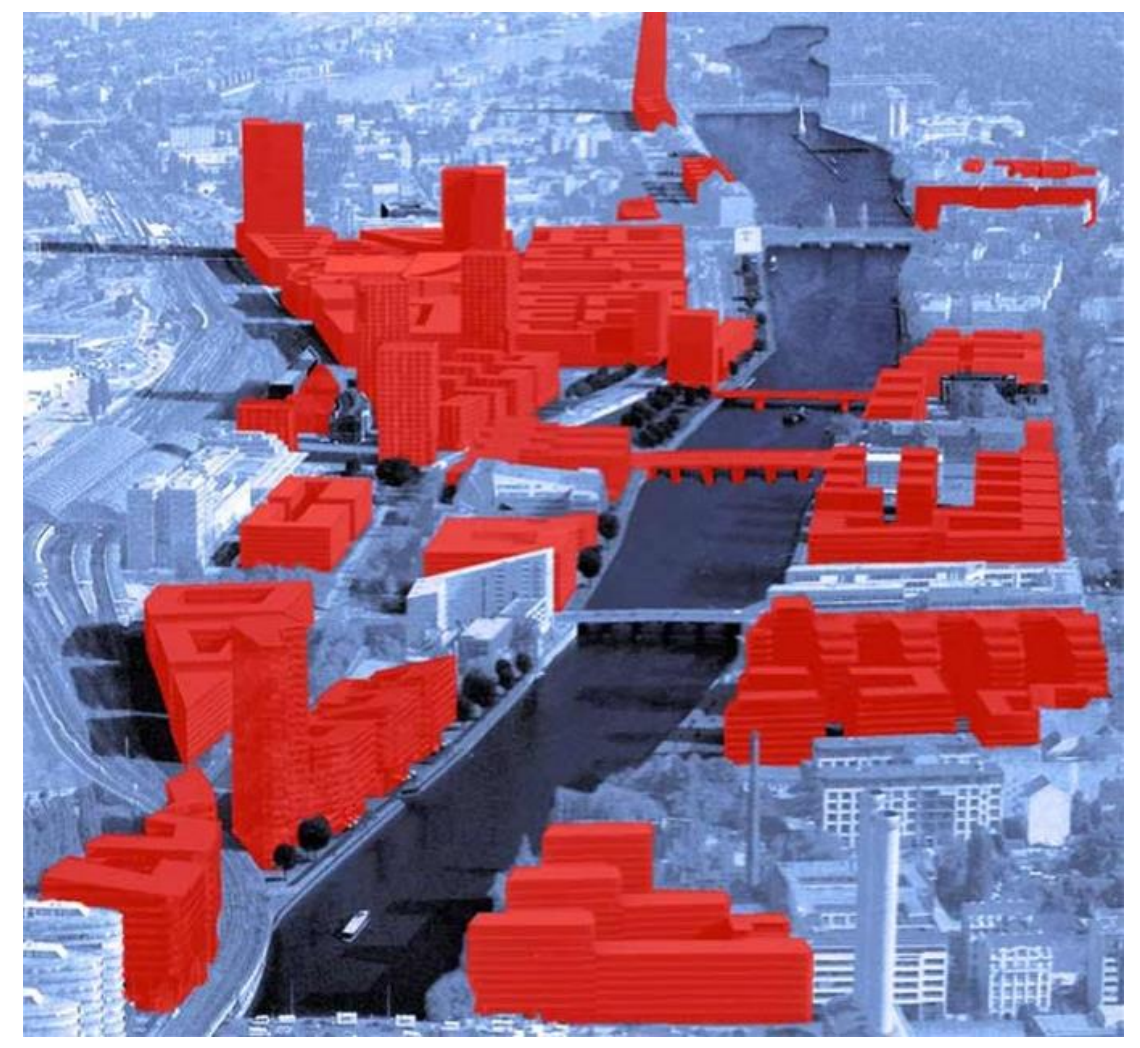

Figure 1 The proposal for development by media spree project scheme
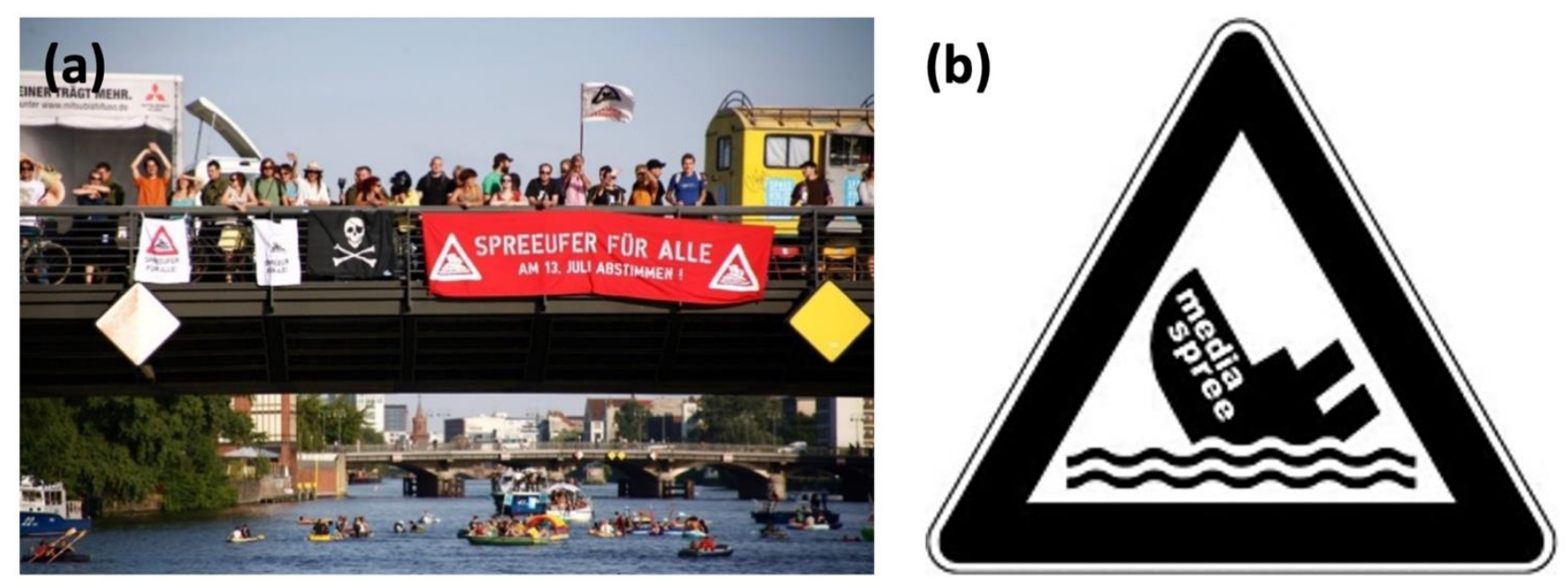

Figure 2a People don't want Media Spree project, massive protests during 2008. 2b protest slogan, "sink media spree" 


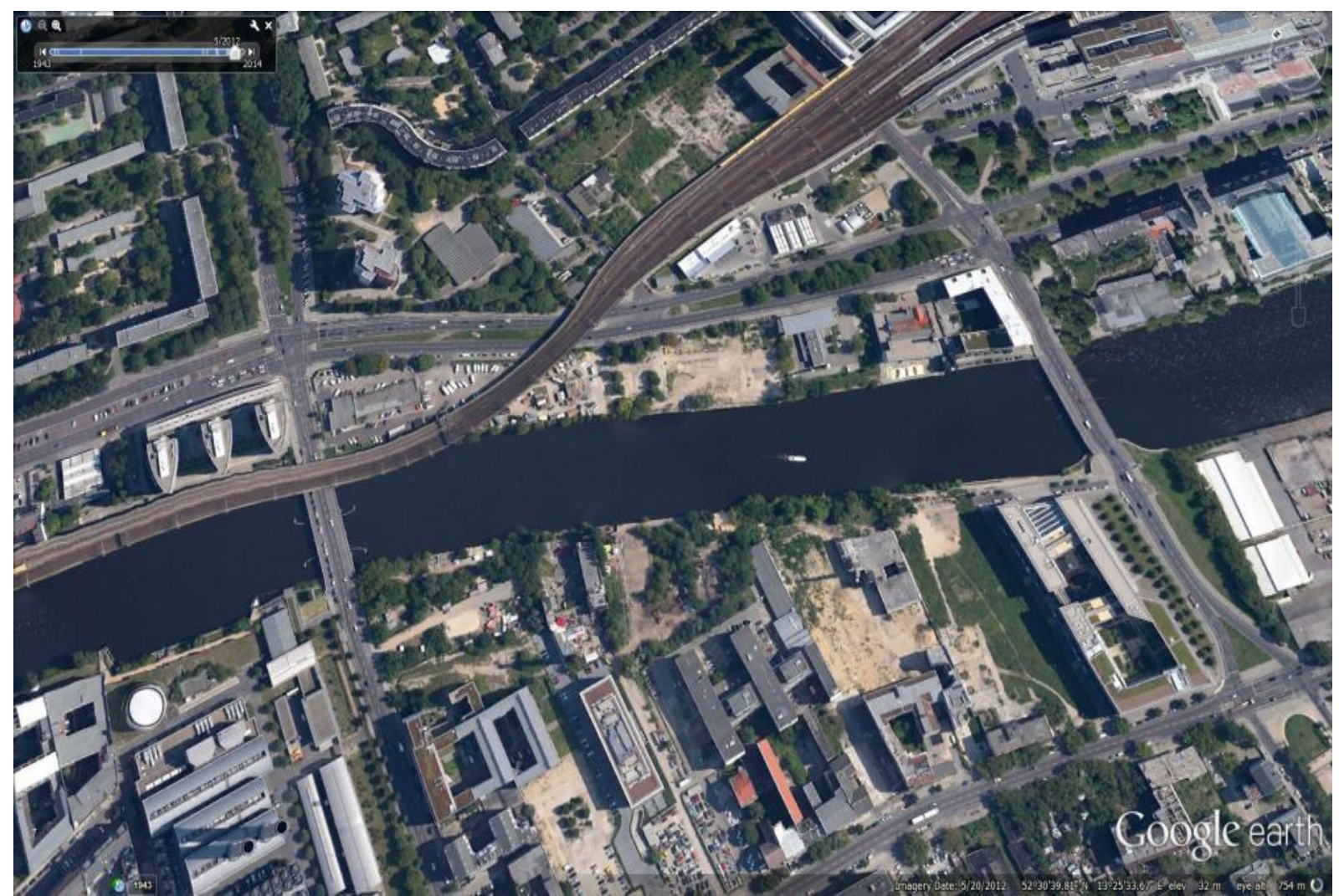

Figure 3 Google image of the site, 2016

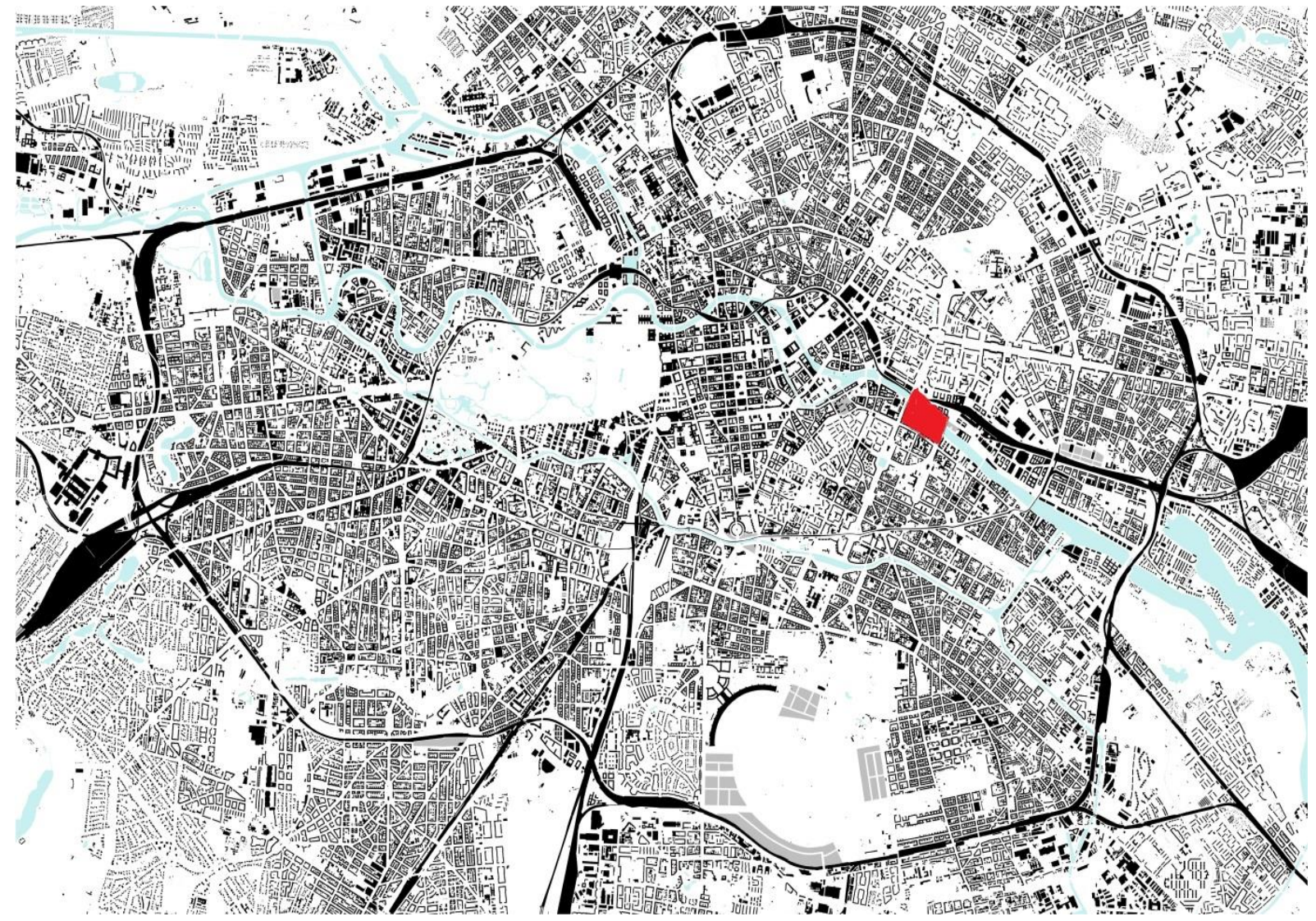

Figure 4 Location of the site in Berlin metropolitan area 

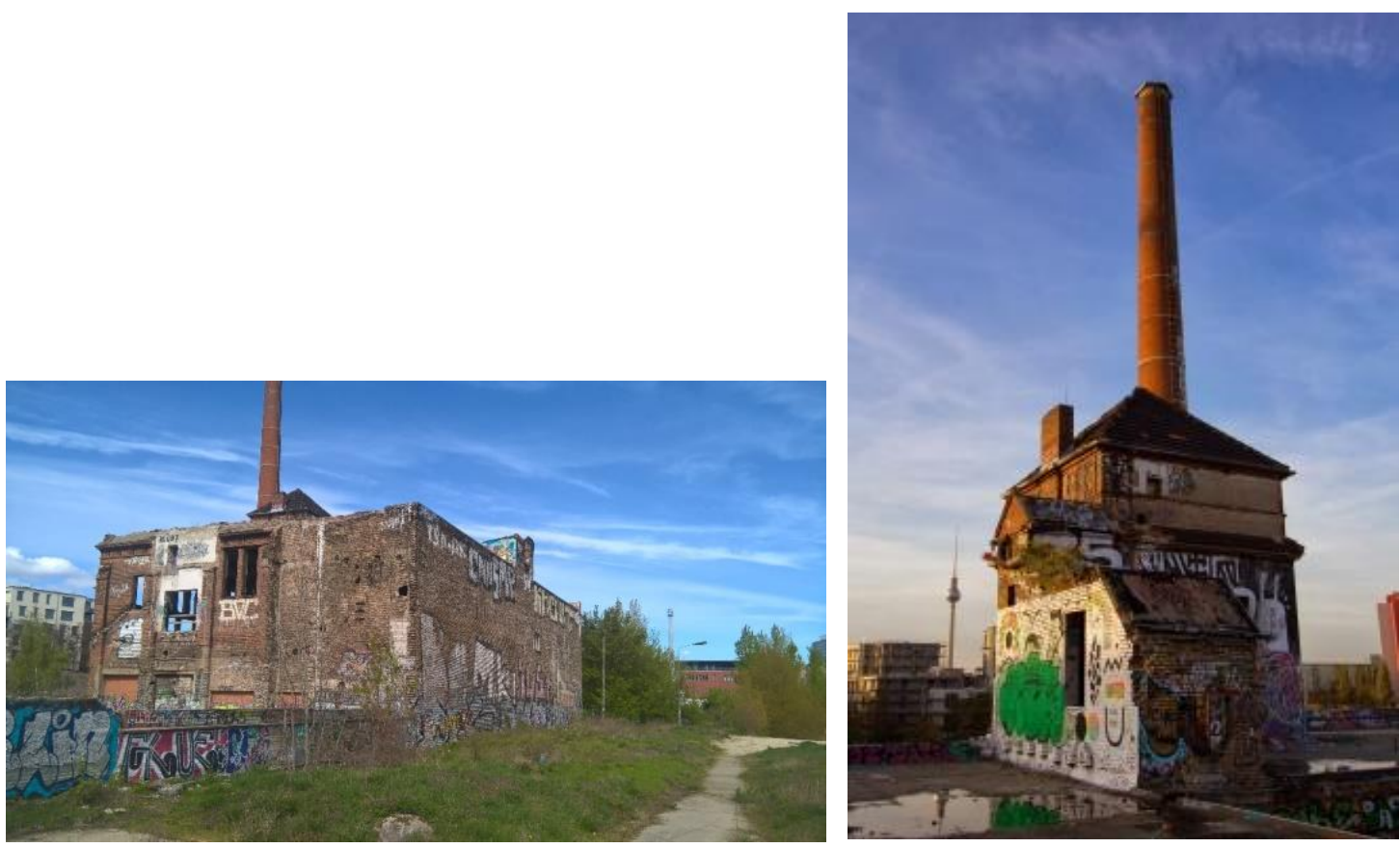

Figure 5a-b First and second enlisted industrial monument in the site, Eisfabric; during the field survey, on $19^{\text {th }}$ April, 2016

\section{Methods}

1. First, analysis of site context with existing regulatory, planning instruments of Berlin in simple free hand sketches to identify positive aspects.

1. The direct, indirect and induced indicators from cultural heritage on the entire city system were identified to assess both the impacts of the project on the buildings themselves and the urban context.

2. The participative phase was based on the involvement of different inhabitants through interviews aiming at understanding the reasons why these urban spaces have different impacts and success as a distinct public culture.

3. A field survey was conducted with focused user group (FUG) and experts at local level including representatives of institutions and academic scholars were involved.

4. Deduction and critical analysis of results to derive design solutions. The design itself was segregated into four stages of assessments in the design studio class under the supervision of assigned teachers.

5. Some limitations were acknowledged and excluded during the research. For example, Adaptive Reuse Potential (ARP) Model, developed by Langston and Shen in 2007 and AdaptSTAR developed by Sheila Conejos- were not utilized in this study.

The flow of research is illustrated below:

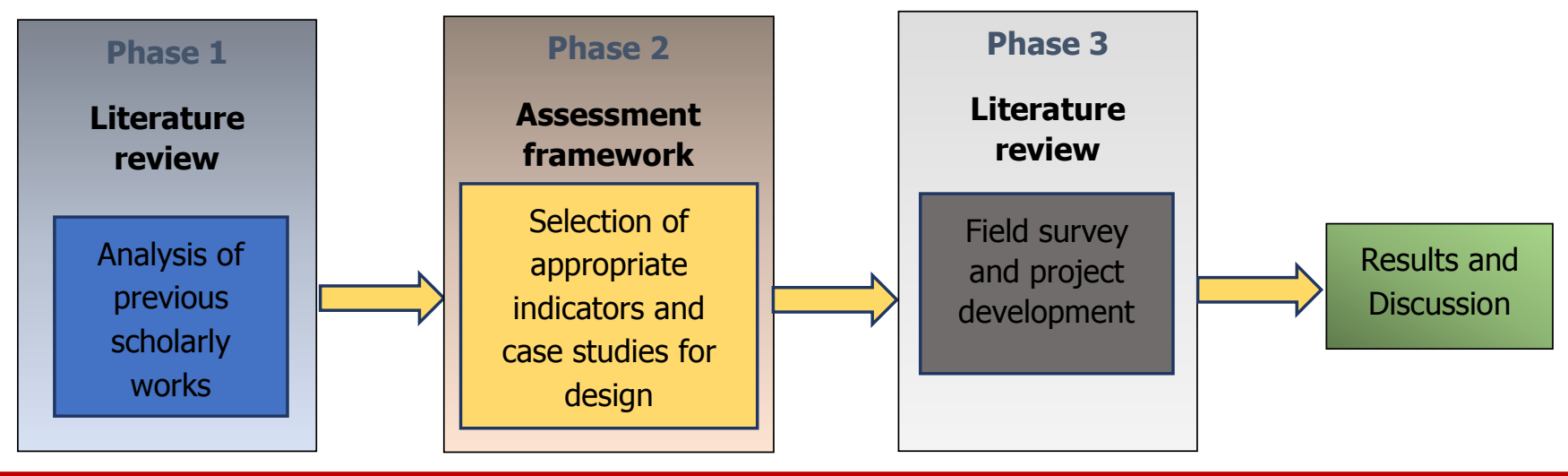




\section{Literature review}

The dilapidated industrial monuments are not assessed from their values and have become burden, and even subjects to knockdown all around world. Today's industrial sites need to establish an intelligent and dynamic relationship with our "recent past". (Rubino, 1978). There are multiple factors at stake (political, social, economic, technical, regulatory, cultural, business, management, etc.) which are necessary to answer multiple questions by involving multiple disciplines. (Beccatini, 2000). Adaptive re-use gives new life to a site, rather than seeking to freeze it at a particular moment in time, it explores the options that lie between the extremes of demolition or turning a site into a museum. Adding a new layer without erasing earlier layers, an adaptive reuse project becomes part of the long history of the site. It is another stage, not the final outcome. (Justine Clarke, 2013) (Mosler, 2015). International Council on Monuments and Sites (ICOMOS) in its Burra Charter, outlined seven principles that will help to deliver successful adaptive reuse projects. Form a multi-disciplinary design team, engaging stakeholders, maintaining the quality and essence of heritage and finally, developing a financial model for ensuring life-cycle investment in the long run. (ICOMOS, 2014) When a previously inhabited land or building has become obsolete, adaptive reuse is a strategy to increase the site's potential value in aesthetic, structural, and characterful ways. (Burchell and Listokin, 1981). Adaptive reuse projects should combine five principles: fulfill the purpose of redesigned function, endure for a long time and adapt to new uses, react well and improve the quality of its context, be visually coherent and pleasurable for users as well as passers-by, and have sustainable qualities. (Wilson, 2010). An important issue in adaptive reuse projects is related to the "admissible limits for changing", and thus related to the compatibility between intrinsic values and innovative values. Values linked to history and collective memory are known as intrinsic, while new use values that is the problem related to the suitable "choices" and need meticulous decision making are known as adaptive value. (Girard et al, 2019) The reuse project involves a preliminary evaluation of the building, to identify criteria for the preferable design choices. These derive from the system of values ascribed to the building and its potential use. (Highfield, 1987) A wide-ranging scientific literature on the subject of reuse highlights the potential benefits on an urban and territorial scale, such as the increase in the market value of soils and buildings, social promotion and economic development in the surroundings. (Simons and Choi 2010) Three modes of alteration which include intervention, insertion, and installation, all these notions of remodeling and transformation are indeed pragmatic and widely accepted in practice. (Brooker and Stone, 2004) The viability of creative reuse depends on the imagination and will of the designer, followed by the skill and ingenuity. It is a holistic approach that encompasses aesthetic appeal, functional considerations, economic value and psychological needs of city inhabitants. (Latham, 2000) Scholars like Rappaport believes, distinguishing the meanings in three different levels, locates in the upper meaning, fundamental values related to the cultural patterns, philosophical systems, and religious identity of a community. (Rapoport, 1982)

\section{Case studies}

a. Tallinn, Estonia: It is the Cultural Cauldron which is basically a regeneration of industrial building for cultural center and the whole ancient district. It transformed the area from hippie niche to creative powerhouse. (Figure 6) This renewal project was modeled after the scheme of Smart growth and the flagship of Europe's 2020 Strategy and concentrates over three values:

i) Focusing on innovations that address the major societal challenges,

ii) Pursuing a broad concept of innovation,

iii) Involving all actors and all regions in the innovation cycle. The Cultural Cauldron in Tallinn is a former power station with an area of 10000 square meters. It is strategically located near the sea front between the port and its medieval old town. The 'Cultural Cauldron' project is a creative combination of a 'soft' and 'hard' development, the renovation of a physical facility and creating a new platform for networks and knowledge to inspire leadership and initiative. It successfully negotiated from initial voluntary phase to broad partnership strategy and now, it became indispensible part of Tallinn's cultural life. (EU Urban development Report, March 2013)

b. Baltimore Inner Harbor plan, USA: This is the most successful waterfront renewal project in America. It ensured a process for sustainable economic, social, and cultural revitalization. In fact, it's a worldwide 
model for waterfront revitalization. The plan initially included a 240 -acre one-block deep area around the water's edge and predicted investments of $\$ 260$ million over thirty years. Later, plans for Inner Harbor West and East were approved. Inner Harbor Plan included five major components: high quality commercial and office buildings along the waterfront; multifamily housing in the eastern and western areas; a low mandatory build-to cornice line for buildings in the block immediately surrounding the waterfront and commercial uses at the street level; no permission for tall building on the waterfront but existing iconic towers will sustain; and lastly, the waterfront featured parks, public areas and a wide promenade to become a successful urban civic space. (Figure 7) The commitment to social responsibility proved to be good for business, generating an attractive mix of ethnic restaurants and retail that became one of its strong communal features. In its first years, the aquarium was generating 3,000 jobs and $\$ 88$ million to the local economy. Depopulation was Baltimore's and its downtown's most difficult problem to solve but inner harbor resolved it with its attraction, and people preferred to live closer to downtown after 80's (Rio, 2007).

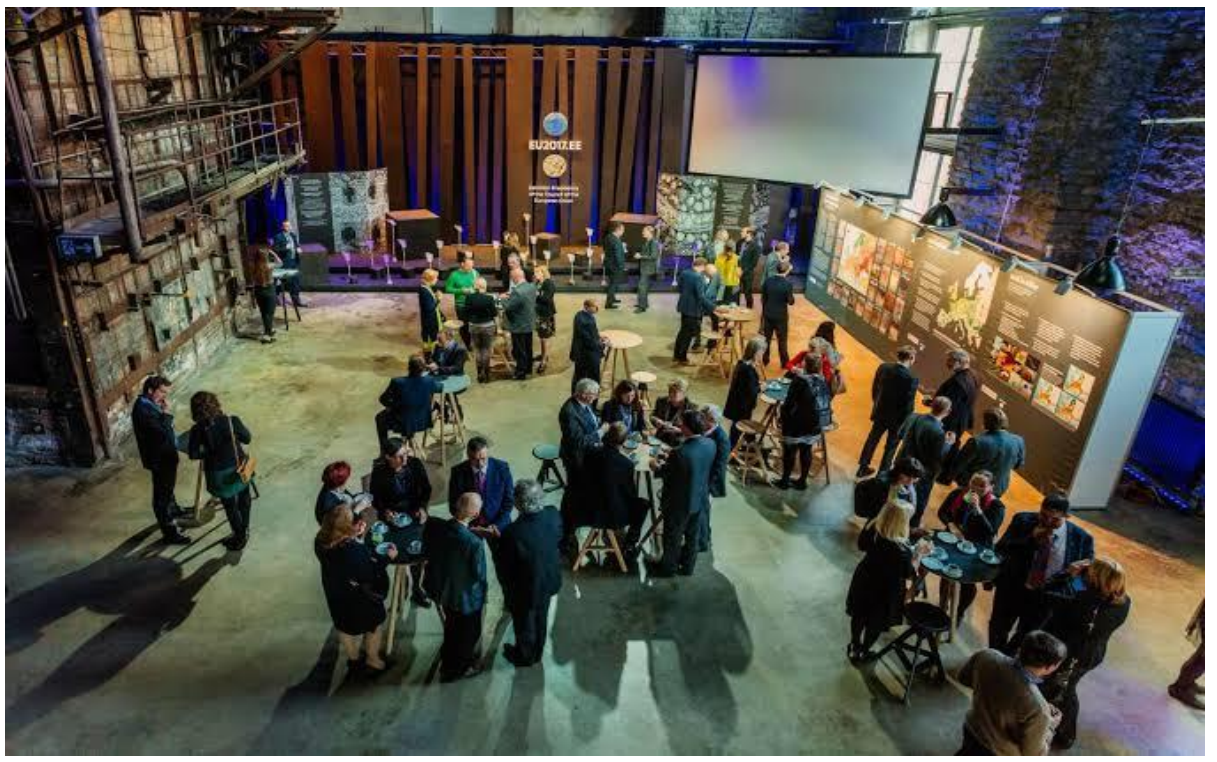

Figure 6 Cultural Cauldron, from industrial heritage to creative hub of Tallinn city. Source: KAVAKAVA.com

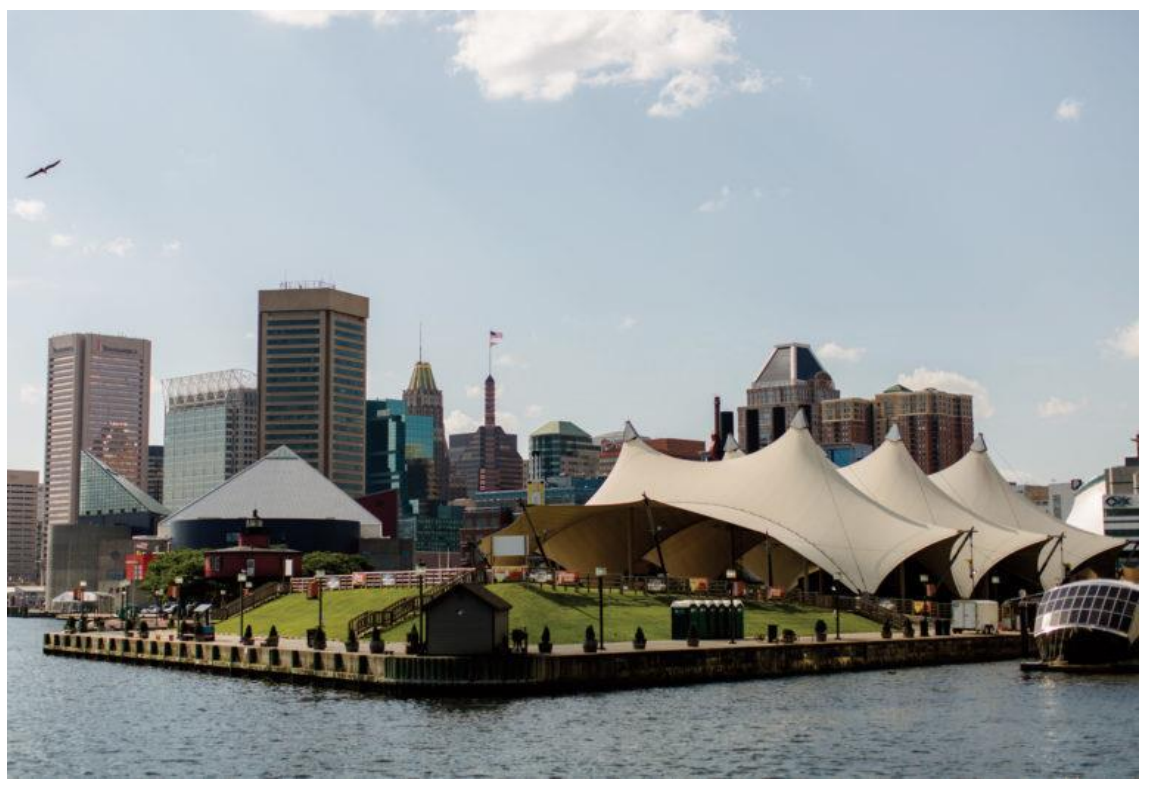

Figure 7 Waterfront regeneration project in Baltimore Inner Harbor, Maryland; USA. Source: visitbaltimore.com 


\section{Field Survey}

Studio teachers took all the students to a daylong trip in Berlin for an extensive site survey where several emergent questions were asked about their protest, dream and challenges they faced so far. "How such recreational drives, genuine informal vive and civic interpretations are sustaining in the site, while the city has lots of other amusements to offer? How adaptive reuse, conservation and preservation techniques, community based strategies could be rewarding for this area instead of any robust developments or Tabula Rasa? What can we do to preserve industrial heritage site and turn these into beneficial projects both from economic and cultural prospect instead of knocking down built forms or leaving spaces with negligence?" All the answers of the respondents could be summed up simply like this: Such unique site provides intimacy with nature to breathe free and calmness from the hustles of metropolitan life. It poses vibrant urban cultures like Beer and party clubs, cuisine, quality pastime for friends and family. It is also epicenter of Berlin's graffiti art, (Figure 8) thus became meeting and greeting places for the artists and sculptors. Open public spaces over the river shore are getting extinct in Berlin which pushed them to an end: "Spree riverfront for all". (Figure 9a \& 9b) The city dwellers own it and they will decide its fate, will also not allow or trust any authorities to establish any haphazard and random development. But there are some problems too. Vagabonds, drug dealings and homeless people's unhygienic ghettos posed certain security and social glitches. (Figure 10a, 10b) Lack of parking space is another acute problem of this area and the respondents demanded it. A free river shoreline of 50 meters was their prime concern to conserve.

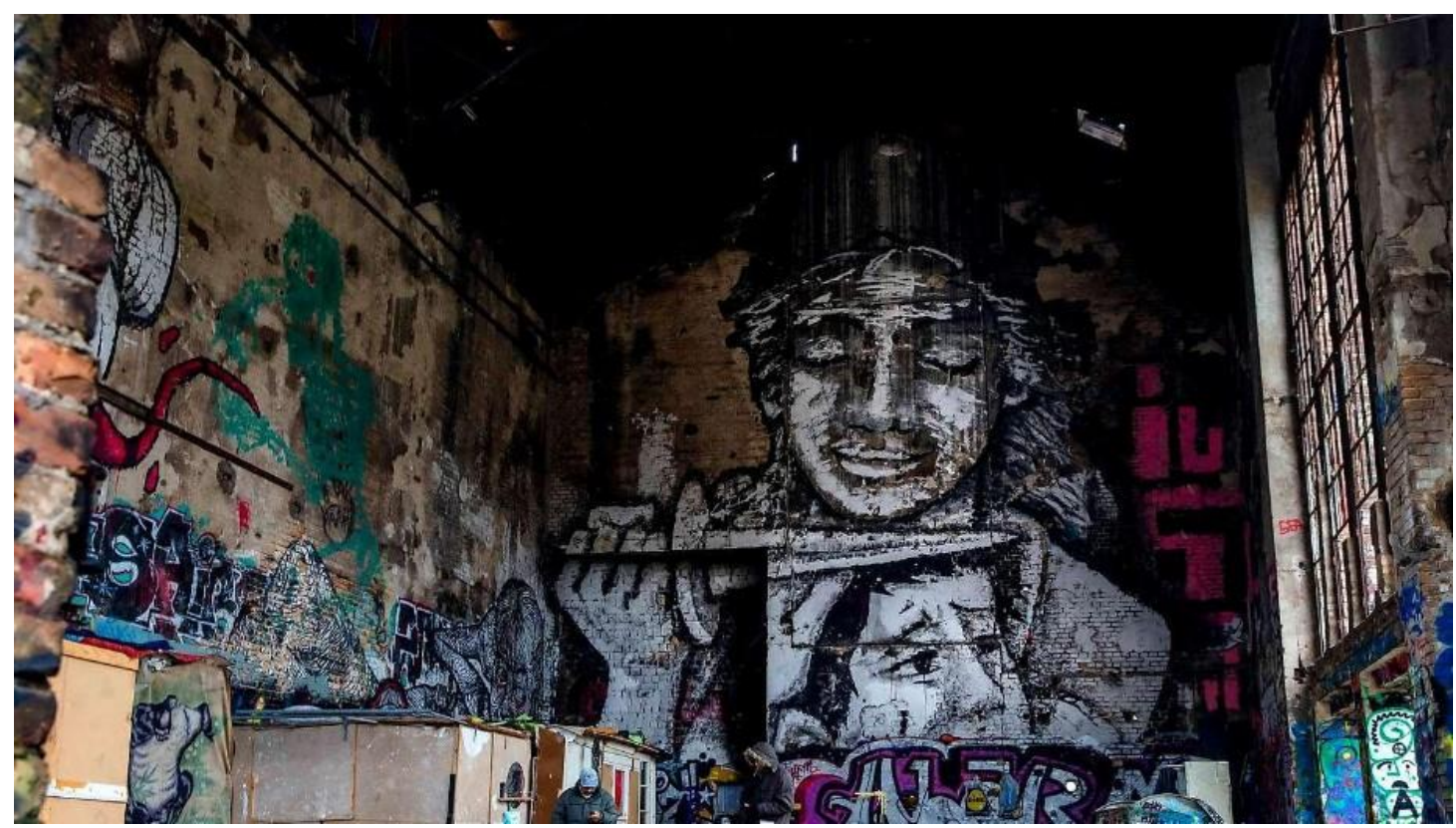

Figure 8 Inside the industrial buildings, Graffitti art flourished.
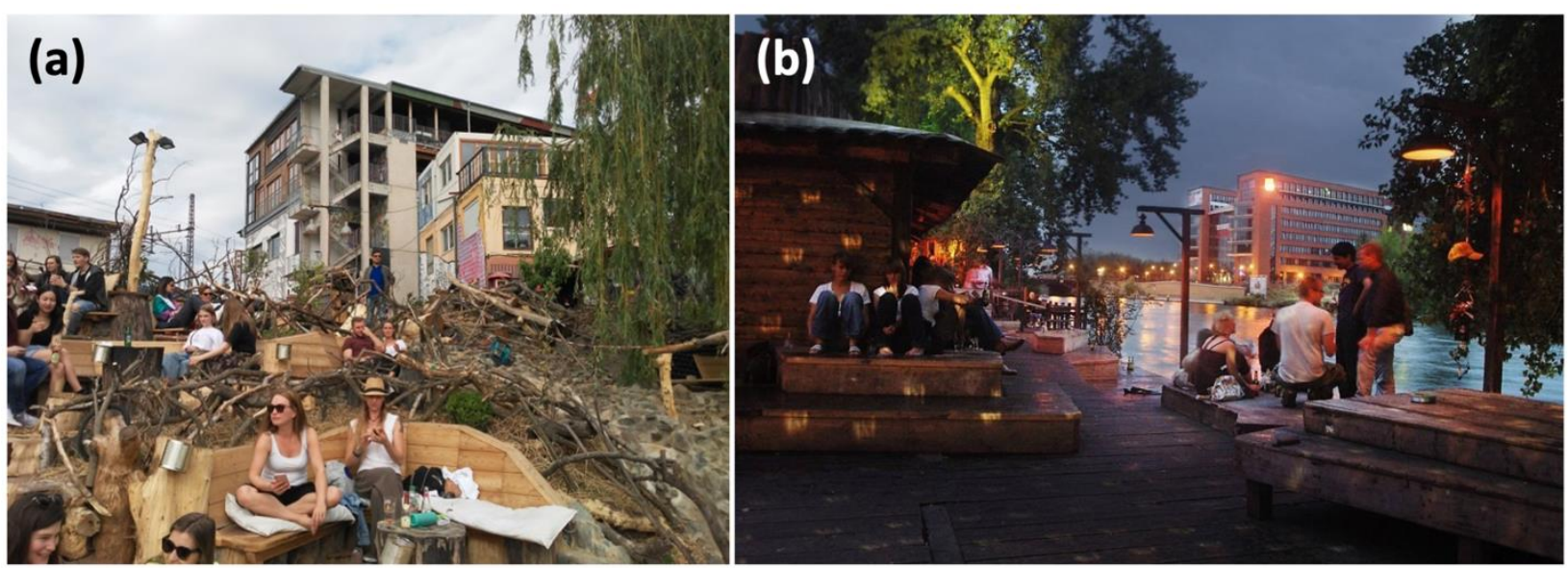

Figure 9a Public gathering during afternoon 9b People like to drink here at weekends and developed pub culture 

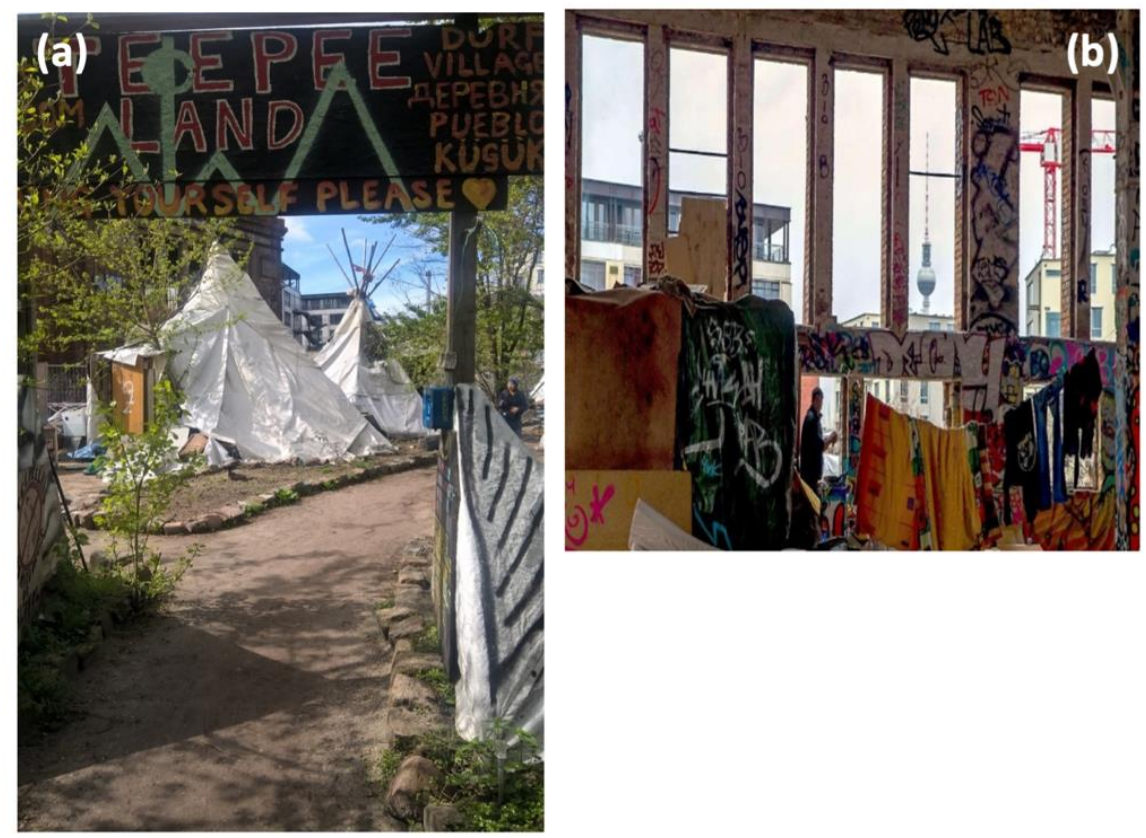

Figure 10a Tents of homeless peoples $10 \mathrm{~b}$ Homeless people also took their shelters.

\section{Site Analysis}

Site specific information like its historic development, old pictures, maps and master plans were collected. Literature reviews related to site's origin, previous planning concepts, expansion, change and continuity, land use regarding public and private ownerships, socio-cultural physiognomies etc. were premeditated thoroughly. A lot of sketches were produced for better understanding of existing spaces' essences. Enactment of analysis techniques revealed natural characteristics by freehand sketches that depicted site location, topography, landscape properties, visual and sonic qualities, and climatic features.

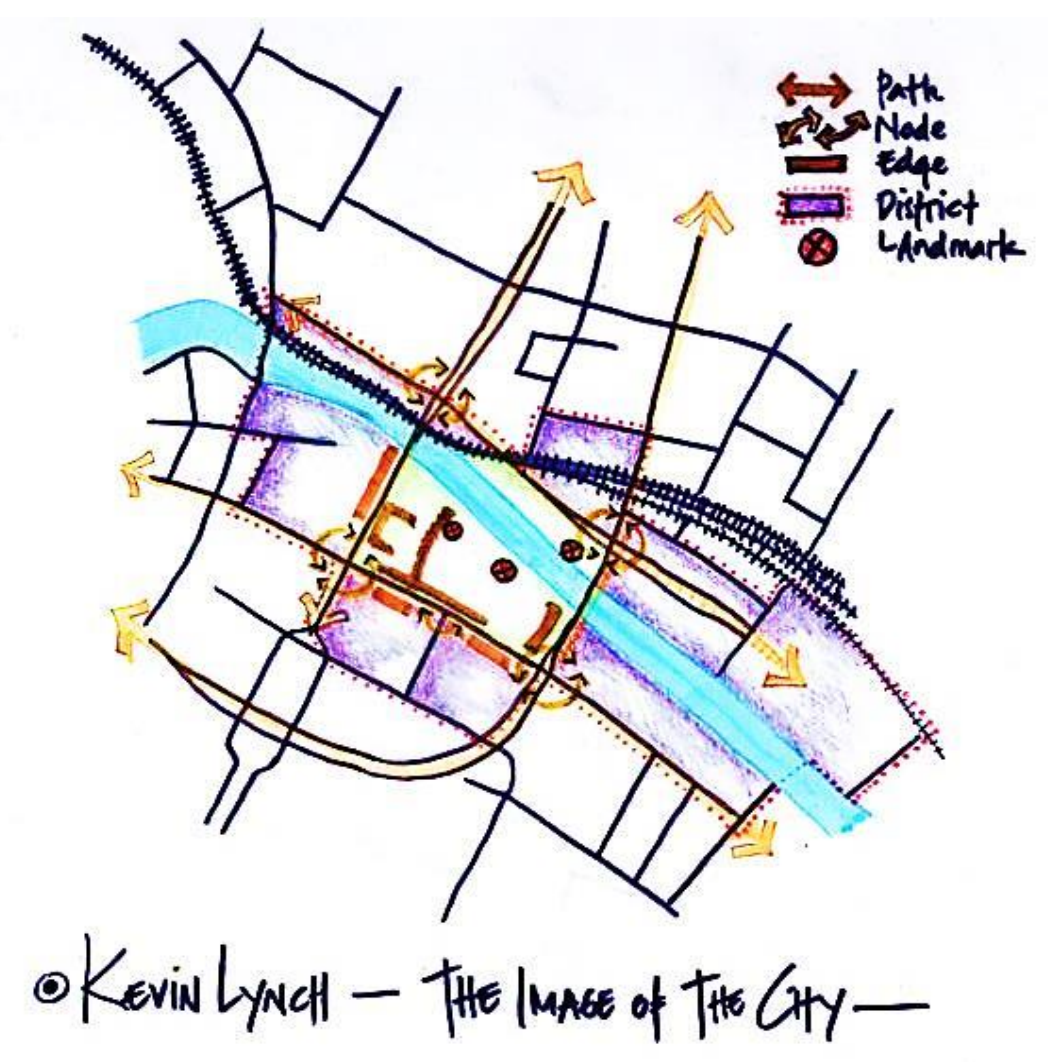

Figure 11 Analysis of site's image according to Kevin Lynch 


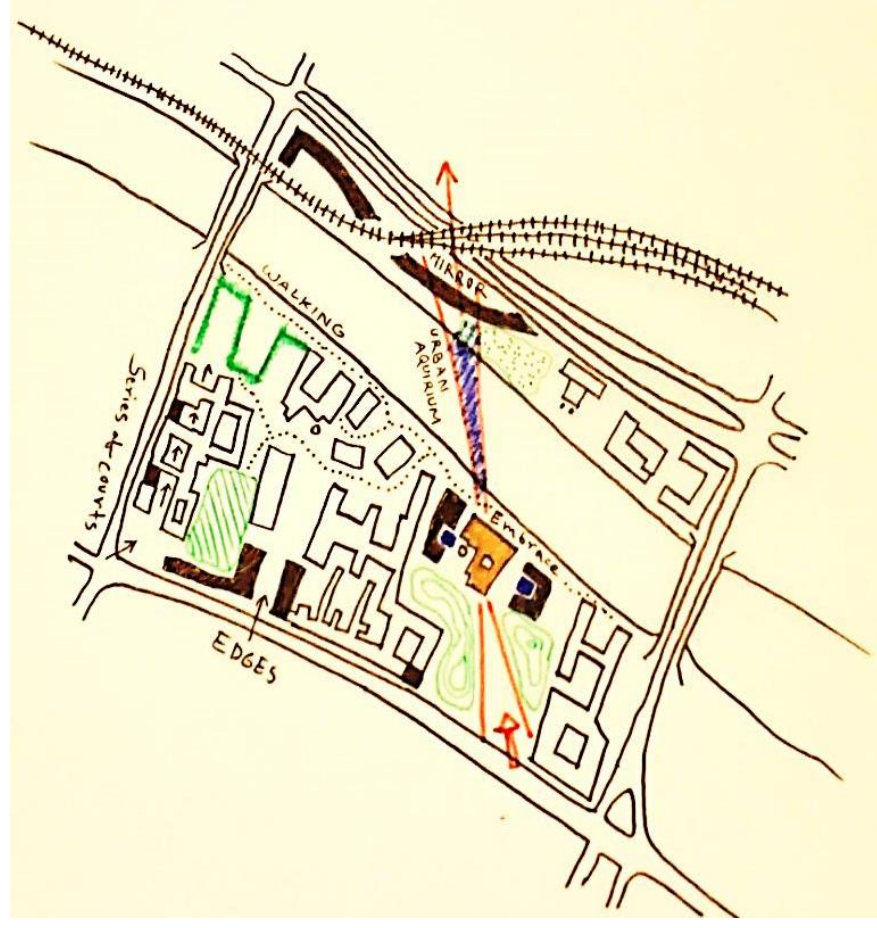

Figure 12 Design potentials identified from existing positive features of the site.

Built environment study according to Kevin Lynch's image of city was followed by identifying elements: path, districts, edges, landmarks and nodes. (Figure 11) Physical or man-made characteristics, pattern of urban fabric, figure ground and reverse figure ground, street network, spatial organization, hierarchy of open spaces and architectural typologies in sketches helped to distinguish the scopes and strategies in design decisions. It is evident now that the entire site owns many positive aspects and the inhabitants have great expectations over these memory built up spaces. (Figure 12)

\section{Results and discussions}

\section{Design interventions and proposals}

Collective memories ${ }^{1}$ of the inhabitants found from field survey were used to derive the Adaptive reuse ${ }^{2}$ principles for the overall site. Despite having a historic segregation after WWII, the site remained like a 'socialist tissue' that gives actual essence of Berlin Wall and once its historic DDR era surroundings. But some mixture with eastern Berlin to western Berlin is still missing. The site's neighborhood and the two shores of Spree River might be linked by a 'Bridge' to germinate a connection hub. The famous Bridge of BAUHAUS inspired as a connecting idea. Prior challenge was to make the abrupt and abandoned heritage building, whole river shore, cultural activities over on the opposite site and neglected spaces tied into an Axis. The renewal project will start dialogues between leftover spaces with mild interventions, which proposed as 'Spreemix.' Such 'mixing' will provide potential diversity and offer series of experiences to explore hierarchy from various directions: above and around and also surroundings. It's entrance invites the visitors with water fall sounds and gradually takes them to the river bed area where people will explore a vast tunneled aquarium equals to the width of the river stretching 25 meters in length. The underwater and transparent glass aquarium will showcase the ecological settings and 56 species of fauna of river Spree. Below the average depth of water (5 meters), the tunnel is adjacent to the river bed, so that it might not cause any navigation problem and ensure the clearance for underwater view inside. Such aquarium is something new and unique, which the city of Berlin is currently 'not posed with' but later can be proud of.

\footnotetext{
${ }^{1}$ It is a tool and trend that the people of certain area used to do with hereditary and leaving marks of it in the places by everyday activities which could be both intangible and tangible at the same time.

${ }^{2}$ It is a changing or existing pattern of use for any heritage site or built form which will ensure sustainable functioning in todays' and future need.
} 
Incentives to convert the brown fields into suitable green spaces are only possible through reviving its lost landscape under the HUL recommendations ${ }^{3}$. The stepped sandy river shore line remains undisturbed with existing greens by maintaining a distance of 50 meters, which was the prior demand of the protesters. On the east side, a serpentine greenhouse with series of courtyards was proposed from the inspiration of existing court configurations and modeled after the prevailing human walk flow. Here, both indoor-outdoor harvesting options were provided to respond with the weathers of winter and summer respectively. Inside the transparent green house, different trees will still be present in the winter, so the site is not going to be a barren snowy field in the coldest month like January, when temperature drops to $-1^{\circ} \mathrm{C}$. The green house is attached to the Eirkuhler building which is converted as Flora museum in the design proposal. The surrounding built spaces of Eisfabric building (Ice Factory) is designed in such way that both new buildings seem to bow down and showing respect to the monument. These are ornate with roof terrace and glassy facades so that users can enjoy the proximity of industrial heritage turned into a Fauna Museum. These factories were responsible for polluting this city once, turned into lungs for its dwellers by the dint of adaptive reuse. Such river based ecological museums didn't exist before in Germany, even in a populous city (3.4 million) like capital Berlin. During the snow fall, these engulfing building's roofs and surrounding landscapes will become skating rink. During the summer time, recreational and leisure spaces in the mounds beside the entrance are designed to accommodate barbeque zone, playing spots for children, dog walking path etc. The design also generated a parking area with capacity of 108 vehicles in middle. The opposite side of the river is already a well-established vibrant cultural center. Its exhibiting perfect combination of informal architecture: used ships, abandoned containers, broken deck etc.

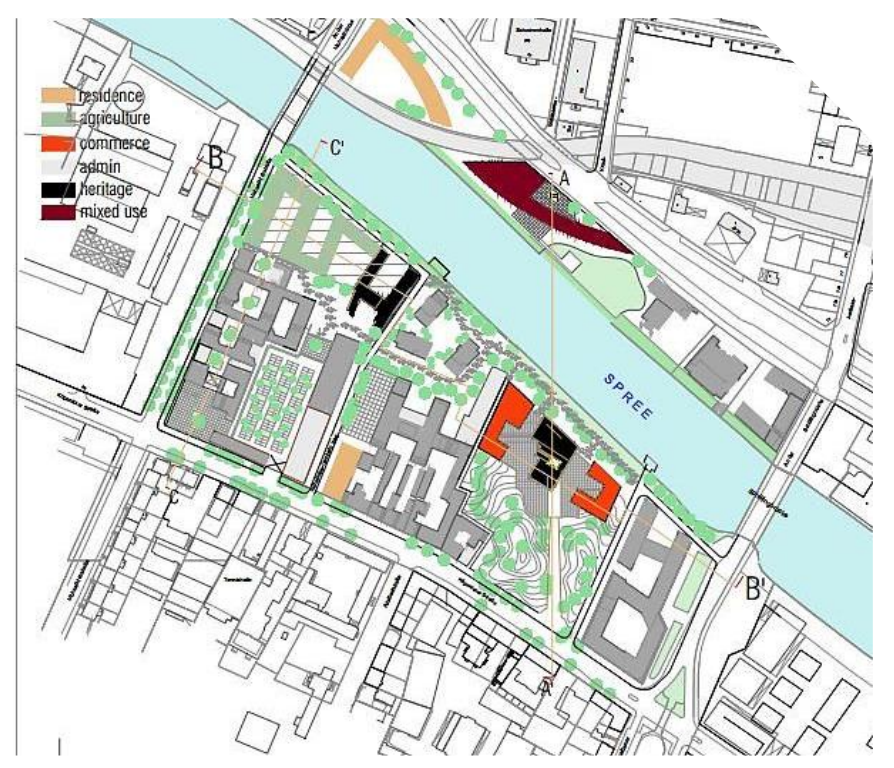

Figure 14a. Heritage buildings (black masses) with existing built forms (grey) and footprints of new proposals (yellow, red, brown and green). AutoCad drawing by author.

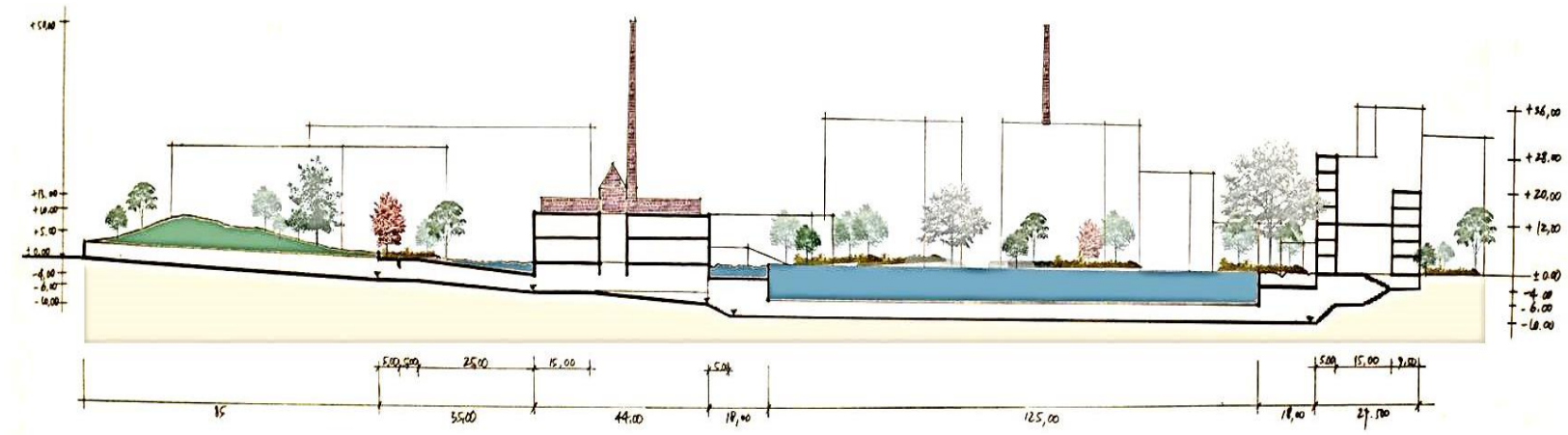

Figure 14b. The Axis, connecting series of spaces and experiences into a single force. Section 1

\footnotetext{
${ }^{3}$ Sustainable development frameworks in the historic city districts are recommended by UNESCO's 36 th session in 2011, known as Historic Urban Landscape (HUL) initiative including the motto "New life for historic cities". It defined some prerequisites from holistic and integrated approach to balance contemporary urban infrastructures with existing cultural heritages.
} 


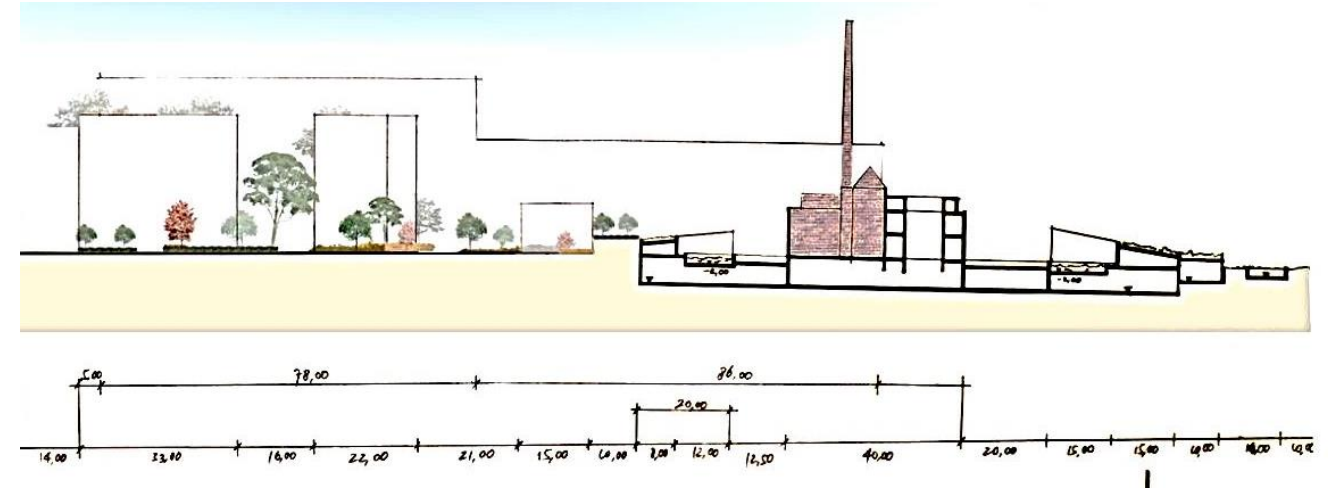

Figure 14c. The heritage building, Eisfabric was respected in new design by merging the built forms with landscape, section 2

This informal character was not erased, rather improvised with feasible, integrated and innovative environment in the design proposal. Only a free built form of structural skeleton in a flip footprint compared to Ostbahnhof Rail tracks is proposed to minimize the dominant sonic and visual force of the railway station over the whole Holzmarkt area. It was designed to confirm the maximum building height restriction of 22 meters for Berlin. Its ground floor will be a free flowing double floor height built form and will include diversified functions like pubs, snacks culture, music stations, night clubs, rides etc. which are also evident in existing situation. There will be free accessible lots in the upper floors for painters, Graffiti worms and sculptors. These floors are proposed to host regular exhibitions, conferences, symposium and seminars, sale center for art pieces and antiques (Figure 13a, b, c).

\section{Findings and analysis}

The environmental challenges human kind is facing due to increased and extreme climate phenomena, necessity for sustainable and ecofriendly cities are very obvious for betterment of next generations. In addition, the recent experience of living during a global pandemic has emphasized the significance of a 'tolerant coherence' between human with natural environment along with its fauna and flora diversities.

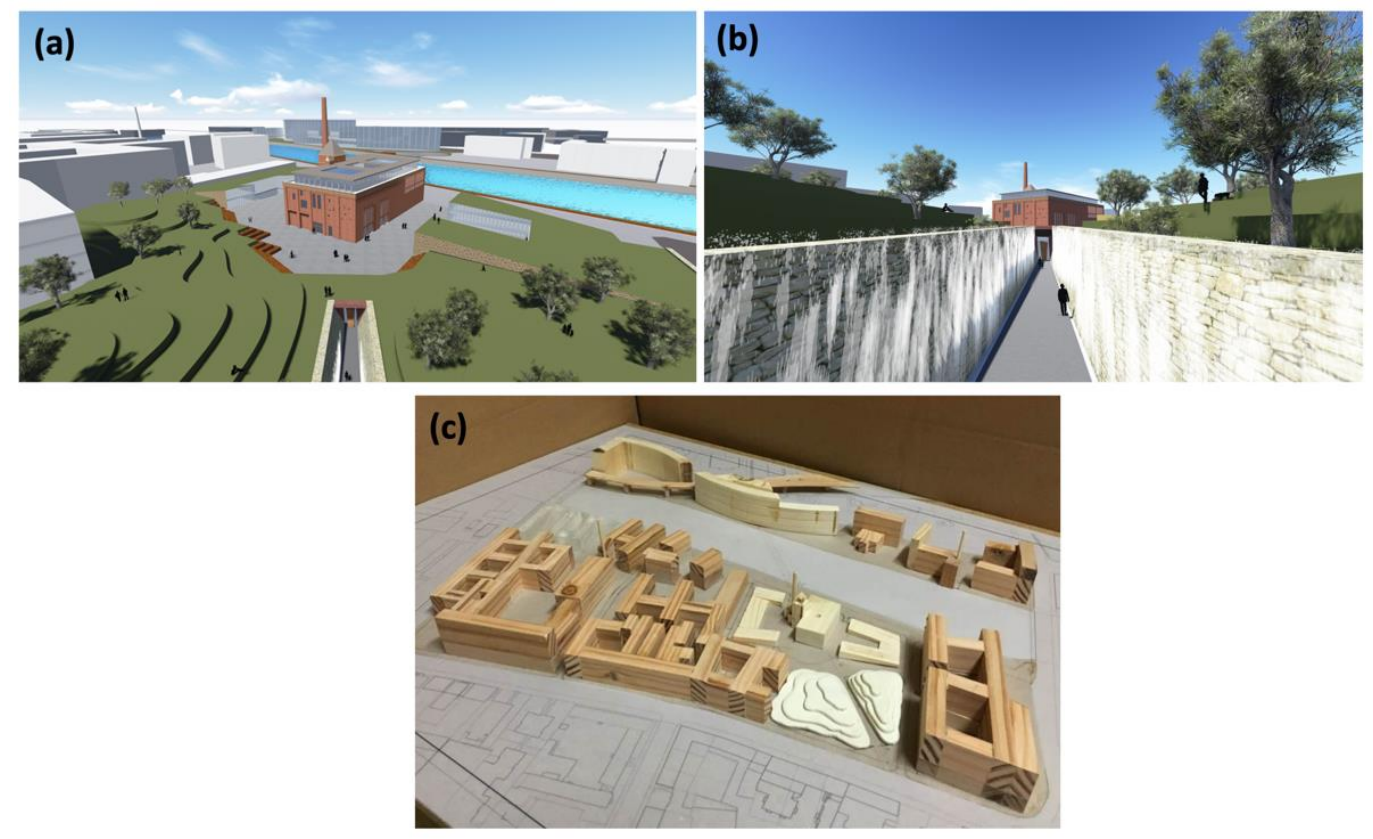

Figure 14a Adaptive reuse: renovation of heritage buildings and landscape interventions b Proposed entrance view c Wooden study model 
It's also important in order to support our physical and mental health by preserving existing natural settings and even enhance it instead of robust and rapid urbanization. Additionally, Current urban practice is underlined by a major view point which is a malpractice: adopting only mass produced technological tools and built environment that promise 'resilience in a box' but it does not reflect the whole scenario. Therefore, the access of open spaces in urban or densely populated areas is becoming non-negotiable in recent years. An environmental or sustainable approach in urban design, infrastructure and any kind of development could be seen as 'a one-way route' in the response to the climate disasters and crisis around the globe. Such intervention could be achieved through collaboration between multidisciplinary and pioneer concepts that is embedded with environmental as well as economic benefits for future sustainable cities. In addition to these, the design outcomes revealed by the urban studio class demonstrates how assets of existing heritages, public policy and social strategy and multidisciplinary teams which were could be adopted by all. Achieving such goal of resilient cities is not an easy exercise, but it is achievable. Determination, strong leadership, willingness to identify the new ways of thinking and cross-silo collaboration are key steps for such innovation over cityscape. The power of landscape design to reveal the value of land, memories and sense of belongingness has been identified as a significant factor in changing perceptions and creating visions. Biodiversity of water and urban aquarium concept was perfect exuberance in design thought from such inspiration. If used effectively, the major role of this design outcome will encourage future urban design and planning policy to convert urban communities into environmentally and energy efficient adobes, without sacrificing their assets like given natural settings and cultural heritages. The built environment represented in wood model and 3d modeling by sketch up reflected the design idea properly (Figure 14a, b, c).

\section{Conclusion}

The design project tried to analyze and understand how the vacant building and its surroundings could be embedded in an urban regeneration strategy and developed from 'the bottom up' urban regeneration process as well as more universal reuse models. However, this article is limited for development of a conceptual design framework and has limitations in the terms of applicability in different cultures and regions. But it will rise further fundamental questions regarding the usefulness and analyzing of such complex projects: site selection, renovating abandoned buildings and Historical monuments by reactivating with different functions, urban regeneration and redevelopment strategies, admitting comparisons, allowing speculations and calculating success rate of every initiatives. The locations of urban hubs and architectural elements are relative to the importance and application of such remodeling to convert them as major cultural content and physical forms of any city. According to the above descriptions which are indicated, two main points could be explained as the results of this study. Firstly, one main cultural axis is formed in addition to the basic historic elements on the river spree and tied up two urban fabrics of Berlin, east and west. The tie was proposed through a biodiversity tunnel which is again not so boring rather gives a pleasing experience with unusual biological conservation initiative with different kinds of activities are proposed in both winter and summer seasons. Secondly, industrial architecture along with residential quarters and commercial land use are brought under cohesion by the dint of adaptive use: holding art exhibitions, homeless rehabilitation, graffiti practice, museum and urban agriculture. But still Public and private spaces are separated exactly from each other and thus ensured maintenance, protection and repair of designed landscape and built forms as inhabitants can feel that they 'own' it which will act as the most important step of this area's recovery and motivate the citizens against privatization of broadcasting medias, which were their prior demand. And for both results, 3 basic aspects need to be ensured: Management, control and community supervision.

\section{References}

Australian International Council on Monuments and Sites (ICOMOS) Burra Charter Office for Design and Architecture, (2014), Design Guidance Note 1.2.1: Adaptive Reuse. Government of South Australia.

Beccatini, G., (2000), Distretti industriali e sviluppo locale, Bollati Boringhieri, Torino.

Brooker, G., Stone, S., (2004), Rereadings: Interior architecture and the design principles of remodelling existing buildings, Riba Enterprises, London. 
Burchell, R.W., Listokin, D., (1981), The adaptive reuse handbook: procedures to inventory, control, manage, and reemploy surplus municipal properties, Rutgers University, N.J, New Brunswick, Center for Urban Policy Research.

Clark, Justine, (2013), Adaptive Re-use of Industrial Heritage: Opportunities \& Challenges, Heritage Council Victoria, Melbourne.

Fusco Girard, L., Nocca, F., Gravagnuolo, A., (2019), Matera: City of nature, city of culture, city of regeneration: Towards a landscape-based and culture-based urban circular economy, Aestimum, 74. https://doi.org/10.13128/aestim-7007

Highfield, D., (1987), The Rehabilitation and Re-Use of Old Buildings, Spon Press, London, UK.

Latham, D., (2000), Creative re-use of buildings, Donhead publishers, Shaftesbury.

Mosler, S. (2015). Heritage politics in Adelaide. University of Adelaide Press ODASA (2014). Design Guidance Note: Adaptive Reuse, Office for Design and Architecture South Australia, Government of South Australia. Last retrieved on 09/11/2016: http://odasa.sa.gov.au/site/wpcontent/uploads/2015/11/1.2.1-Adaptive-Reuse140725-FV.pdf

Project Outcomes and the Role of Tax Credits. Cleveland State University, 13, 79-108.

Rapoport, A., (1982), The Meaning of the Built Environment: A Nonverbal Communication Approach, SAGE Publications, New York.

Rio, Vicente del. (2007), From Downtown to the Inner Harbor: Baltimore's Sustainable Revitalization, Part 2: The Inner Harbor Plan (1967 to 2005), Focus 14 Essays, 62-76.

Rubino, G.E., presentazione di A. Venditti, (1978), Archeologia industriale e Mezzogiorno, Giuditta, Rome.

Simons, R.A., Choi, E., (2010), Adaptive Reuse of Religious Buildings in the U.S.: Determinants of Urban Development in the Eu: 50 Projects Supported by the European Regional Development Fund During the 2007-13 Period, (2013), Chapter 3, Smart Growth, Pp 12-13.

Wilson, C., (2010), Adaptive reuse of industrial buildings in Toronto, Ontario: Evaluating criteria for determining building selection.

Acknowledgments: During the summer $\left(2^{\text {nd }}\right)$ semester of author's Masters Course, the university offered an urban studio, from March to September, 2016. Thanks to his two favorite teachers, Damoun Vahabi Moghaddam and Sepideh Zarrin Ghalam from Architecture and cultural heritage course of Anhalt University of Applied Sciences at world famous BAUHAUS campus, Dessau. The studio was dedicated to study 'Adaptive Reuse' concept in urban scale and students were guided to follow the HUL recommendations. As a project, it contested in Student Charette competition for World Architecture Festival in 2016 and the theme was 'Mix'! Along with only 7 other projects around the world, this design was shortlisted for final presentation on 16-17th November in Berlin.

Does this article screened for similarity: Yes

Funding: No funding was received for conducting this study.

Conflict of Interest: The Author has no conflicts of interest to declare that they are relevant to the content of this article.

About The License

(C) The author 2021. The text of this article is open access and licensed under a Creative Commons Attribution 4.0 International License

\section{Cite this Article}

Sayed Ahmed, Conceptual Urban Renewal Outlines Against Proposed Mediaspree Project at Holzmarkt Area in Berlin: A Proposal to Remodel Vibrant Urban Space, Asian Journal of Interdisciplinary Research, 4(4) (2021) 17-29. https://doi.org/10.54392/ajir2143 